\title{
Sondringen mellem grammatiske og leksikalske præpositioner
}

\author{
Maria Messerschmidt, Kasper Boye, \\ Mathilde Marie Overmark, \\ Sofie Theilmann Kristensen \& Peter Harder
}

\begin{abstract}
The class of prepositions is not a homogenous class with respect to grammatical status. Some prepositions can be classified as lexical and others as grammatical. In this paper, we argue that modifiability is a diagnostic criterion which can be used for such a classfication, and we provide an approach to the analysis of prepositions based on this criterion. The analysis is demonstrated on several Danish prepositions, and the classification is then tested against data from an agrammatic speaker.
\end{abstract}

Nøgleord: præpositioner, grammatik, leksikon, modificérbarhed, agrammatisme

\section{Indledning}

I mange tilgange til lingvistisk teori opdeles ord i to slags: dem, der tilhører leksikon, og dem, der hører under grammatikken. De to slags ord betegnes ofte som hhv. indholds- og funktionsord, og det antages som regel, at de første danner åbne ordklasser, mens de sidste danner lukkede klasser. Men sondringer mellem grammatik og leksikon, som er baseret på indhold vs. funktion og åbne vs. lukkede ordklasser, er problematiske. Betegnelserne og kategoriseringen antyder, at funktionsord ikke har indhold, og indholdsord ingen funktion, og det er selvfølgelig ikke tilfældet. Desuden implicerer henvisningen til hhv. åbne og lukkede ordklasser, at alle elementer i en 
given ordklasse må have samme status som enten grammatisk eller leksikalsk. Dette er heller ikke tilfældet. Sammenlign fx har i eksempel (1) og (2).

(1) Søren har to missede opkald.

(2) Søren har misset to opkald.

(3) Sørens to missede opkald.

I eksempel (1) er har et leksikalsk fuldverbum, der udtrykker en slags ejerforhold, og i eksempel (2) er det et grammatisk hjælpeverbum. Have tilhører den åbne ordklasse verber i begge tilfælde, og selv om man antog en underordklasse af hjælpeverber, som var lukket, ville den overordnede ordklasse stadig være åben.

Det er heller ikke sådan, at det indhold, der kan udtrykkes med et leksikalsk element (som ejerforholdet i (1)), kun kan udtrykkes på denne måde. I (3) er et lignende ejerforhold udtrykt med det grammatiske suffiks -s. Nogenlunde det samme indhold kan altså udtrykkes af enten et grammatisk eller et leksikalsk element, og den samme ordklasse kan indeholde både grammatiske og leksikalske elementer.

Verber er det prototypiske eksempel på en ordklasse med både grammatiske og leksikalske medlemmer, men det er ikke den eneste ordklasse, der på denne måde er heterogen. Der er flere af de såkaldt lukkede ordklasser, der har medlemmer af begge typer. Undersøgelser har fx vist, at selv den relativt lille (og lukkede) klasse af pronominer i både fransk og dansk indeholder både grammatiske og leksikalske elementer (Brink 2014; Ishkhanyan et al. 2017). Men især klassen af præpositioner er interessant i denne sammenhæng. Eftersom de udgør en lukket klasse, er det naturligt at opfatte dem som grammatiske, og det gør nogle (fx Harley 2006: 77, 118; jf. Chomsky 1981: 48). Andre hæfter sig ved, at præpositioner har egenskaber, der findes hos klart leksikalske elementer - fx kan de tilskrive kasus - og ser dem som leksikalske, på trods af at de udgør en lukket klasse (fx Jackendoff 1973; Leikin 2002). Atter andre ser præpositioner som grammatisk-leksikalske hybrider (fx Mardale 2011; Bordet \& Jamet 2010) eller netop som en heterogen klasse, som omfatter både leksikalske og grammatiske medlemmer, der kan skelnes fra hinanden ved muligheden for substitution (Friederici 1982; grammatiske præpositioner er dem, der ikke kan substitueres), på semantisk grundlag (se fx Littlefield 2005; grammatiske præpositioner er dem, der har begrænset eller intet indhold) eller på grundlag af teoretisk baserede stipuleringer (Kean 1979; grammatiske præpositioner er dem, der styres af en syntaktisk regel). 
I denne artikel argumenterer vi på baggrund af teorien om sondringen mellem grammatik og leksikon i Boye \& Harder (2012) for, at præpositionsklassen er heterogen. Vi afleder af teorien et kriterium for at skelne mellem leksikalske og grammatiske præpositioner i dansk, hvorpå vi foreslår en klassifikation af udvalgte danske præpositioner. Denne klassifikation efterprøves dernæst $\mathrm{i}$ en analyse af talesprogsdata fra en patient med den type afasi, der kaldes agrammatisme, idet det forudsiges, at agrammatisme påvirker produktionen af grammatiske præpositioner mere end produktionen af leksikalske.

Artiklen er struktureret som følger: I afsnit 2 gennemgår vi kort teorien i Boye \& Harder (2012), idet vi påpeger, at de eksisterende kriterier for sondringen mellem grammatisk og leksikalsk ikke lader sig anvende på præpositioner. I afsnit 3 udleder vi derfor et nyt kriterium af teorien: modificerbarhed. I afsnit 4 demonstrerer vi, hvorledes dette kriterium kan anvendes på udvalgte danske præpositioner. Afsnit 5 og 6 handler om agrammatisme. I afsnit 5 skitserer vi, hvad agrammatisme er, og hvorfor det er særlig relevant at kigge på agrammatiske data i forbindelse med en klassifikation af grammatiske og leksikalske sproglige elementer. I afsnit 6 konfronterer vi først klassifikationen af udvalgte danske præpositioner med talesprogsdata fra en agrammatisk taler for at undersøge, om klassifikationen er ikke bare lingvistisk, men også neurolingvistisk holdbar. Derpå sammenholder vi resultatet af konfrontationen med resultatet af en undersøgelse af fuld- vs. hjælpeverber i agrammatisk tale. Artiklen afsluttes med en konklusion i afsnit 7.

\section{En funktionel teori om grammatisk status}

Boye \& Harder (2012) konfronterer problemerne med de traditionelle sondringer mellem grammatiske og leksikalske elementer, herunder sondringer, der henviser til åbne og lukkede klasser eller til indholds- og funktionsord. Som et alternativ opstilles en usus- og funktionsbaseret teori om, hvad det vil sige, at et sprogligt element er hhv. grammatisk eller leksikalsk. Den centrale ide er, at sondringen mellem grammatik og leksikon er en konventionalisering af en informationsprominenskontrast, som hjælper os med at rette vores opmærksomhed mod det mest relevante i en sproglig meddelelse. Leksikalske udtryk er kendetegnede ved, at de har et potentiale til at udtrykke det primære indhold (dvs. den mest prominente information) i en ytring. I modsætning hertil er grammatiske udtryk kendetegnede ved 
ikke at have dette potentiale. De er konventionelt sekundære og kan ikke bruges til at udtrykke den mest prominente del af en ytring.

Grammatiske udtryk er altså pr. konvention diskursivt sekundære i forhold til et eller flere andre udtryk, som kan kaldes deres værtsudtryk. På grund af denne sekundære status er de strukturelt og indholdsmæssigt afhængige af deres værtsudtryk. Derimod er i hvert fald nogle leksikalske udtryk uafhængige af et værtsudtryk; man kan fx sige brand! i isolation. Når sproglige udtryk kombineres til større helheder, er helheden leksikalsk (i modsætning til grammatisk - dvs. ikke i betydningen 'leksikaliseret som enhed'), hvis den indeholder mindst ét leksikalsk element, dvs. mindst ét element, der har potentiale til at udtrykke det primære indhold i en ytring.

Sproglige udtryk kan klassificeres som hhv. grammatiske eller leksikalske, idet man afprøver, om de kan have diskursivt primær status. Hvis et udtryk kan det, er det leksikalsk. Hvis ikke, er det grammatisk. I Boye \& Harder (2012) opstilles to diagnostiske kriterier for at sondre mellem leksikalske og grammatiske elementer, der begge betjener sig af mekanismer til at markere diskursivt primær status: fokuserbarhed og adresserbarhed. Leksikalske elementer kan fokuseres eller adresseres i den efterfølgende diskurs, mens grammatiske elementer ikke kan fokuseres eller adresseres (i hvert fald ikke uden en korrigerende effekt).

Disse kriterier kan udmøntes i sprogspecifikke test, der trækker på specifikke sprogs ressourcer for fokuserbarhed og adresserbarhed, fx fokuskonstruktioner som sætningskløvning og fokuspartikler (Kristensen \& Boye 2016). Sådanne test har vist sig nyttige i forbindelse med klassifikation af pronominer (fx Brink 2014; Ishkhanyan et al. 2017), men de har nogle begrænsninger, fordi det kun er sætningsled og andre strukturelt selvstændige led, der kan fokuseres og adresseres. Dette giver en udfordring i forhold til netop præpositioner, som typisk er strukturelt afhængige af deres styrelse og derfor ikke kan fokuseres eller adresseres alene. Det er derfor nødvendigt at identificere og afprøve et nyt diagnostisk kriterium, der kan anvendes til klassifikationen af præpositioner. Vi foreslår her modificerbarhed som et sådant kriterium.

\section{Modificerbarhed som diagnostisk kriterium}

Modificerbarhed kan bruges som diagnostisk kriterium til klassifikationen af sproglige udtryk, fordi manglende modificerbarhed er en naturlig - om end ikke logisk - følge af, at grammatiske udtryk har sekundær status: Et udtryk, der er inhærent sekundært, er en dårlig kandidat til elaborering. 
Det er det primære - det, der tiltrækker sig opmærksomhed - der mest oplagt kan elaboreres gennem modifikation. Eller omvendt: Modifikation elaborerer og tiltrækker sig derved opmærksomhed, hvorfor det går dårligt i spænd med sekundær status.

Grammatiske udtryk kan altså ikke modificeres alene, mens leksikalske udtryk, herunder komplekse udtryk, der indeholder et eller flere leksikalske elementer, kan modificeres (jf. også Rauh 1993). Dette kan illustreres med eksemplet i (5), hvor han, løb- og hurtig- er leksikalske udtryk, mens ha(v)-, $-r,-e t$ og - $t$ er grammatiske udtryk. Adverbiet hurtigt modificerer verbet labe, men det kan ikke modificere hjælpeverbet. Og suffikset $-r$, der udtrykker tempus, modificerer ikke hjælpeverbet alene, men hele sagforholdet inklusive perfektumbetydningen. Så selv om tempus morfologisk og udtryksmæssigt står som suffiks på hjælpeverbet, er det altså den større leksikalske helhed, der modificeres af tempus.

Han har løbet hurtigt.

Modificerbarhed er ikke begrænset til sætningsled. Andre leksikalske udtryk kan også modificeres, og derfor er dette kriterium særligt anvendeligt til en ordklasse som præpositioner.

Modificerbarhed som diagnostisk kriterium til klassifikationen af sproglige udtryk som leksikalske eller grammatiske kan i princippet anvendes på alle sprog. Men ligesom for fokuserbarhed er det nødvendigt at definere de sprogspecifikke strategier for de relevante typer modifikation og at udmønte kriteriet i sprogspecifikke test, der kan bruges til at afprøve, om et givet udtryk er modificerbart eller ej i det pågældende sprog.

\section{Modificerbarhed anvendt på danske præpositioner}

I det følgende vil vi opstille en sådan test for danske præpositioner.

\subsection{Strategi og testdesign}

Omdrejningspunktet for testen er, at nogle danske præpositioner kan modificeres af visse adverbier. Fx kan præpositionen for i (6) modificeres af adverbiet kort, i modsætning til hvad der gælder for præpositionen for i (7).

(6) Kort før hende sang han.

(7) *Kort for hende sang han. 
Ifølge modifikationskriteriet er for altså leksikalsk, mens for er grammatisk.

Modifikationskriteriet er forbundet med teoretiske og praktiske problemer, som vi vil løse i det følgende.

Det første problem er, at de adverbier, der kan modificere præpositioner, også ofte kan bruges i andre funktioner, og at det i nogle tilfælde kan være svært at skelne adverbialer i sådanne funktioner fra præpositionsmodifikatorer. Det gælder i en sætning som han sang kort for hende, hvor kort entydigt angiver verbalhandlingens omfang, men kan forveksles med en præpositionsmodifikator, fordi det er placeret umiddelbart før præpositionen. For at udelukke sådanne forvekslinger har vi i en del af eksemplerne i denne artikel flyttet præpositionsfrasen (inklusive modifikatoren) op i sætningens forfelt for at disambiguere læsningen. Dette er fx tilfældet i (6) og (7).

Det andet problem er, at hvis en præposition skal kunne modificeres selvstændigt, kræver det ikke blot, at den er modificerbar og dermed leksikalsk, men også at det modificerende adverbium er semantisk kompatibelt med den. Præpositionen for kan fx modificeres af kort, som vi har set, og på kan modificeres af midt, men det omvendte er ikke tilfældet: Præpositionen for kan ikke modificeres af midt, og på ikke af kort.

Det kan tænkes, at der ikke til alle leksikalske præpositioner hører et semantisk kompatibelt adverbium. Med andre ord kan det tænkes, at nogle præpositioner er modificerbare, uden at der forefindes et adverbium, der kan modificere det. Hvis det er tilfældet, er modifikationskriteriet uskarpt, idet det så ikke blot klassificerer umodificerbare præpositioner som grammatiske, men også modificerbare, dvs. egentlig leksikalske, præpositioner, der blot ikke har et semantisk kompatibelt adverbium. Omvendt kan man imidlertid antage, at når en given præposition ikke har et semantisk kompatibelt adverbium, er det nok, fordi der ikke er behov for at modificere den - fordi den er grammatisk.

Det tredje problem kan formuleres med et spørgsmål: Hvordan kan vi vide, at det i sætninger som (6) netop er præpositionen, der modificeres, og ikke hele præpositionsfrasen (eller i hvert fald X-bar-teoriens P')? Det kan vi vha. en substitutionstest. En præpositionsfrase, dvs. en præposition plus styrelse, kan fungere som adverbial og kan som sådant normalt substitueres med proformen der (eller evt. $d a$ ). Dette er eksemplificeret i (9), hvor præpositionsfrasen fra (8) på bordet er substitueret med der. 
(8) Han satte vasen på bordet.

(9) Han satte vasen der.

(10) Han satte vasen midt på bordet.

(11) *Han satte vasen midt der.

I eksempel (10) er der tilføjet det modificerende adverbium midt før præpositionsfrasen. Hvis midt modificerede hele på bordet, ville det være muligt at substituere på bordet med der som ovenfor i (9) og samtidig bevare midt som modifikator. Men som eksempel (11) viser, er dette ikke muligt. På bordet kan ikke substitueres med der, mens midt bevares, fordi præpositionen plus styrelse i dette tilfælde ikke udgør en helhed uden modifikationen. Eller sagt på en anden måde: Præpositionen alene modificeres af adverbiet midt, inden denne helhed kombineres med styrelsen. Præpositionen $p a ̊$ i denne konstruktion kan derfor klassificeres som leksikalsk.

Denne analyse indebærer, at præpositionsfraser med leksikalske og grammatiske præpositioner har forskellige strukturelle muligheder. Den traditionelle (X-bar-teoretiske) måde at analysere en præpositionsfrases interne struktur på er illustreret i (12) (fx O'Grady, Archibald \& Katamba 2011: 161). I denne analyse kombineres præpositionen med styrelsen, før modifikationen tilføjes. Denne analyse afspejler, hvordan den interne struktur i en præpositionsfrase med en grammatisk præposition ser ud, da en modifikation i forbindelse hermed ville modificere helheden af præposition og styrelse, men som vi så ovenfor, afspejler den ikke de strukturelle muligheder i en præpositionsfrase med en leksikalsk præposition. En alternativ analyse, der bedre afspejler muligheden for, at en leksikalsk præposition kan modificeres alene, er vist i (13). I denne analyse modificerer midt præpositionen før kombination med styrelsen - præcis den struktur, substitutionstesten afslørede.

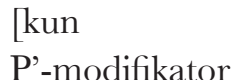

*kort

[for

hende]]

P'-modifikator

Præposition Styrelse

[kun
P'-modifikator

[ [kort

før]

hende]]

P-modifikator

Præposition

Styrelse

\subsection{Prapositionsmodificerende adverbier}

For at kunne udmønte modifikationskriteriet i en dansk test må vi have et inventar af præpositionsmodificerende adverbier. Substitutionstesten, der blev omtalt ovenfor, kan anvendes til at identificere sådanne adverbier. Den 
har dog en begrænsning: Den kan kun anvendes til en mindre delmængde af præpositioner, nemlig dem, der har statisk lokativ eller temporal betydning, fordi disse er semantisk kompatible med proformerne der eller $d a$. Der findes ikke andre simple proformer i dansk, der kan erstatte præpositionsfraser. Det begrænser principielt muligheden for at identificere præpositionsmodificerende adverbier.

Det er dog muligt at identificere en række sådanne adverbier. Vi har allerede set, at adverbierne midt og kort kan modificere præpositioner som henholdsvis på og for. Andre adverbier, der kan modificere præpositioner, er precis, umiddelbart og lige (i betydningen 'præcis'), og der er sandsynligvis flere. Alle disse adverbier kan også have andre funktioner og betydninger, hvor de modificerer andre elementer, og det er derfor nødvendigt at tjekke i hvert tilfælde, at der er tale om den rette betydning af adverbiet. Det er dog kendetegnende for de fleste af disse adverbier, at de ikke kan modificere adverbielle størrelser som $\mathrm{fx}$ præpositionsfraser. Som vist ovenfor i eksempel (11) kan adverbiet midt $\mathrm{fx}$ ikke modificere den adverbielle proform der. Det vil sige, at vi har en gruppe af adverbier, der 1) kan modificere præpositioner og 2) ikke kan modificere præpositionsfraser. Det følger heraf, at alle præpositioner, der kan modificeres med et af disse adverbier, kan klassificeres som leksikalske, og at vi kan udelukke, at det i sådanne tilfælde er hele præpositionsfrasen, der modificeres.

De fleste af de præpositionsmodificerende adverbier, vi indtil videre har identificeret, er forholdsvis snævre i deres betydning, når de modificerer præpositioner. Kort kan bruges om rumlig eller tidslig afstand fra en eller anden ting eller begivenhed, og midt kræver, at der er tale om en flerdimensionel lokation eller en temporal periode, der kan have en midte. Det semantisk bredeste af de præpositionsmodificerende adverbier er lige, og på engelsk er right ('lige') også det præpositionsmodificerende adverbium, der ofte anføres (fx Rauh 1993). Men det danske lige har flere betydninger, og i nogle af dem kan lige, i modsætning til det engelske right, også modificere adverbialer. Sammenlign fx de danske sætninger og deres engelske oversættelser i (14) og (15).

(14a) Han kørte lige til grænsen.

(14b) He drove right to the border.

(15a) Han kørte lige hjem.

(15b) He drove straight home. 
Når det danske lige modificerer en leksikalsk præposition som i (14), kan det oversættes med right og betyder noget i retning af 'præcis' eller 'hele vejen', mens det må oversættes på anden vis i (15), hvor det modificerer adverbialet hjem og betyder 'direkte'. Det, at lige også kan modificere adverbialer som hjem, gør, at det er sværere at bruge dansk lige end engelsk right til at klassificere præpositioner, og vi har derfor foretrukket at bruge nogle af de semantisk mere snævre præpositionsmodificerende adverbier til klassifikation, hvor det er muligt.

\subsection{Eksempler på klassifikationen}

Ifølge Retskrivningsordbogen (Dansk Sprognævn 2017) findes der 93 danske præpositioner. Disse inkluderer både simple præpositioner og morfologisk komplekse præpositioner, men ikke præpositioner, der består af flere ord. Nærværende klassifikation tager udgangspunkt i 11 af de mest frekvente præpositioner (ifølge KorpusDK) og nogle af de konstruktioner, de kan indgå i.

Visse konstruktionstyper er ekskluderet fra klassifikationen. Det drejer sig om idiomatiske eller faste udtryk og tryktabsforbindelser som fx vare helt efter bogen, finde på noget eller stå på bussen, hvor præpositionen ikke kan betragtes som et selvstændigt udtryk, men udgør en del af et (uanalyserbart) leksikalsk hele og derfor ikke kan modificeres. I og med at sådanne præpositioner ikke kan modificeres selvstændigt, kunne vi klassificere disse som grammatiske, men da de andre dele af sådanne helheder heller ikke kan modificeres selvstændigt, ville det blive svært at identificere den leksikalske del af helheden. Vi afstår derfor i første omgang fra at klassificere præpositionerne i denne slags udtryk. Af praktiske årsager har vi heller ikke klassificeret præpositioner i præpositionsfraser, der ikke udgør selvstændige sætningsled, dvs. præpositionsfraser, der fungerer som adled til fx substantiver eller adjektiver. 


\begin{tabular}{|c|c|c|c|}
\hline Præposition & Konstruktion & Klassifikation & Eksempel \\
\hline Af & AGENT[ARG] & GRAMMATISK & Han blev kysset af hende. \\
\hline Efter & TID[ADJ] & LEKSIKALSK & Han ankom efter middagen. \\
\hline Efter & PATIENT[ARG] & GRAMMATISK & Han skød efter hunden. \\
\hline For & BENEFAKTIV[ARG] & GRAMMATISK & Han købte gaven for hende. \\
\hline Før & $\mathrm{TID}[\mathrm{ADJ}]$ & LEKSIKALSK & Han ankom før middagen. \\
\hline Fra & LOKATION/TID[ADJ] & LEKSIKALSK & De festede fra morgenstunden. \\
\hline Fra & KILDE[ADJ?] & GRAMMATISK & De fik støtte fra nogle venner. \\
\hline I & LOKATION[ARG/ADJ] & LEKSIKALSK & $\begin{array}{l}\text { Han kastede mønten i brønden./ } \\
\text { Han tabte nøglerne i butikken./ } \\
\text { Han spiste isen i haven. }\end{array}$ \\
\hline $\mathrm{I}$ & PATIENT[ARG] & GRAMMATISK & Han loeste videre $i$ bogen. \\
\hline Med & KOMITATIV[ADJ?] & GRAMMATISK & Han dansede med hende. \\
\hline Med & THEME[ARG] & GRAMMATISK & Han kastede med bolden. \\
\hline Over & LOKATION[ADJ] & LEKSIKALSK & Han cyklede over marken. \\
\hline På & LOKATION[ARG/ADJ] & LEKSIKALSK & $\begin{array}{l}\text { Han satte vasen på bordet./ } \\
\text { Han hyggede sig på Malta. }\end{array}$ \\
\hline På & PATIENT[ARG] & GRAMMATISK & Han byggede videre på huset. \\
\hline Til & LOKATION[ADJ] & LEKSIKALSK & Han kørte til gransen. \\
\hline Til & MODTAGER[ARG] & GRAMMATISK & Han gav gaven til hende. \\
\hline
\end{tabular}

Tabel 1: Eksempel på klassifikationen. Konstruktionerne er opdelt efter semantisk rolle og overordnet grammatisk relation som verbalt argument [ARG] eller adjunkt [ADf]. Sporgsmålstegn angiver, at vi ikke er sikre på klassifikationen.

Tabel 1 viser en række eksempler på klassifikationen. Som det fremgår, kan flere præpositioner være både grammatiske og leksikalske i forskellige konstruktioner. Eller rettere sagt: For flere præpositionsudtryk er det muligt at skelne mellem grammatiske og leksikalske indhold eller anvendelser - eller at skelne mellem homonyme grammatiske og leksikalske præpositionstegn.

De præpositioner (eller præpositionsanvendelser), der er klassificeret som leksikalske i tabellen, kan modificeres med et eller flere af de ovenfor omtalte præpositionsmodificerende adverbier. Analyserne af præpositionerne for, for og lokativisk på er gennemgået ovenfor (jf. eksemplerne (6)-(7) og (8)-(10)). I det følgende gennemgår vi kort analysen af patientmarkerende på samt analyserne af efter, $i$ og til.

Lokativisk på kan modificeres af adverbiet midt (jf. eksempel (10) ovenfor) og må følgelig analyseres som leksikalsk. I modsætning hertil kan det patientmarkerende på i (16) ikke modificeres, og det må derfor være grammatisk; det er ikke muligt at skrive midt på teorien.

*Han skrev midt på teorien. 
Ved visse andre styrelser som $\mathrm{fx}$ bogen eller tavlen ville det være muligt at modificere $p a ̊$ i en sætning som (16), men da ville modifikationen netop fremtvinge en lokativisk, leksikalsk læsning af $p a ̊$.

Ligesom på har efter og $i$ også både leksikalske og grammatiske varianter.

(17) Han ankom kort efter middagen.

(18) *Han skød kort efter målskiven.

(19) Han sad og læste midt i haven.

(20) *Han sad og læste midt i bogen.

Det sekventielle eller temporale efter i (17) kan modificeres af kort og må således klassificeres som leksikalsk. Det atelicitetsmarkerende efter i (18) kan derimod ikke modificeres af kort, og det må således være grammatisk. Tilsvarende kan det lokativiske $i \mathrm{i}(19)$ modificeres af midt, mens det atelicitetsmarkerende $i \mathrm{i}(20)$ ikke kan. Det første $i$ må derfor være leksikalsk, og det andet grammatisk.

For præpositionen til er analysen en smule mere kompliceret. Både foran det direktionelle eller lokativiske tili (21) og foran det modtagermarkerende til i (22) kan der indsættes et pracis eller et lige.

Han kørte lige til grænsen.

Han gav blomsten lige til hende.

Men kun i (21) modificerer lige præpositionen. I (22) modificerer det styrelsen. Dette kan ses af, at det i (22) er muligt at bytte rundt på rækkefølgen af lige og til, så præpositionsfrasen bliver til lige hende. Kun det direktionelle eller lokativiske til i (21) er altså for en nærmere betragtning leksikalsk; det modtagermarkerende til i (22) er grammatisk.

Der er et klart mønster i, hvilke præpositioner der er grammatiske, og hvilke der er leksikalske. I præpositionsfraser med roller som LOKATION og TID er præpositionerne leksikalske, mens de i præpositionsfraser med andre roller er grammatiske. Til gengæld synes der ikke helt at være en sammenhæng mellem leksikalsk eller grammatisk status og den grammatiske relation som argument (styret led) eller adjunkt (ikke-styret led). LOKATIONER kan være argumenter eller adjunkter, og nogle af de øvrige roller kan også være adjunkter, selv om de fleste er argumenter.

De grammatiske præpositioner svarer altså overordnet set til dem, der angiver kasus eller aktionsart ( $\mathrm{f}$ atelicitet), mens de leksikalske præpositioner inkluderer de rent lokative og temporale. Og for de lokative og temporale kan 
det i nogle tilfælde være vanskeligt at afgøre, om en præposition i en given konstruktion kan modificeres eller ej, især når styrelsen er mere abstrakt.

Børnene i klassen fik kage.

(23) kan forstås på to måder. Der kan enten være tale om børn, som har et socialt tilhørsforhold til klassen, eller om børn, der har et fysisk tilhørsforhold til klassen. Hvis man tilføjer det præpositionsmodificerende midt entydiggøres (23) dog, så der må være tale om et fysisk tilhørsforhold. Både forskellige betydningsnuancer af præpositionerne og forskellige styrelser i præpositionsfraserne kan gøre indholdet mere eller mindre konkret eller abstrakt. Når en præposition ikke kan modificeres, kan det som ovenfor omtalt for én betragtning skyldes dens grammatiske status, men det kan også skyldes semantisk inkompatibilitet. For denne betragtning er kriterierne til at afgøre et udtryks status altså kun diagnostiske; de er ikke fuldstændig skudsikre.

\section{Agrammatisme og grammatik}

Agrammatisme er en betegnelse, der dækker over en gruppe symptomer, der kan findes i Broca's afasi, og som er centreret omkring en svækket evne til at producere grammatiske udtryk, inklusive affikser, grammatiske ord og mere eller mindre skematiske konstruktioner (Thompson \& Bastiaanse 2012). De klassiske symptomer inkluderer udeladelse og substitution af grammatiske morfemer og ord samt langsom, opbrudt tale, hvor der primært bruges korte, simple helsætninger. Der findes mange forskellige teorier om agrammatisme, men de har alle det til fælles, at de anerkender, at agrammatikere hovedsageligt har problemer med grammatik. Analyser af agrammatisk tale er dog oftest baseret på en præteoretisk fornemmelse af, hvad der er grammatisk, og hvad der ikke er, eller på teoretisk problematiske sondringer som sondringen mellem indholdsord og funktionsord eller mellem åbne og lukkede ordklasser.

En mulig forklaring på den klynge af symptomer, der udgør agrammatisme, er, at det er et udtryk for nedprioritering af en del af den information, vi normalt formidler sprogligt - en nedprioritering, som er nødvendiggjort af, at agrammatikere har reducerede kognitive ressourcer (Caplan 2012). Boye \& Harders (2012) teori kan supplere her med en motivation for, hvorfor det netop er de grammatiske elementer, der er særligt ramt. Ifølge teorien er de grammatiske elementer konventionelt sekundære og udtrykker baggrundsinformation. Skal man derfor spare på ressourcerne 
og kun producere det absolut mest nødvendige, er det oplagt at droppe de grammatiske elementer til fordel for de potentielt mere prominente leksikalske elementer.

Der findes undersøgelser af agrammatikere, der fokuserer på forskelle inden for en enkelt ordklasse. Friedericis (1982) studie af afatikeres processering af præpositioner undersøgte tysktalende agrammatiske og paragrammatiske talere (dvs. talere med hhv. en ikke-flydende og en flydende afasiform) eksperimentelt for at finde ud af, om de havde sværest ved syntaktiske ( grammatiske) eller semantiske ( leksikalske) præpositioner. Hun fandt, at de agrammatiske talere havde sværere ved at producere de syntaktiske præpositioner end de semantiske.

\section{Prapositioner og verber i agrammatisk tale}

I det følgende gennemgår vi to undersøgelser af talesprogsdata fra en agrammatisk taler: en undersøgelse af præpositionsproduktionen (Overmark 2017) og en af verbalproduktionen (Kristensen 2017). Formålet med den første undersøgelse var at afprøve, om sondringen mellem leksikalske og grammatiske præpositioner på baggrund af modifikationskriteriet understøttes af agrammatiske taleproduktionsdata. Formålet med den anden var at afprøve, om en sondring mellem leksikalske fuldverber (have i konstruktioner som jeg har en cykel) og grammatiske hjælpeverber (have i konstruktioner som jeg har cyklet) på baggrund af fokuskriterierne i Boye \& Harder (2012) understøttes af agrammatiske data. I nærværende sammenhæng tjener sidstnævnte undersøgelse som referenceramme for den første: Hvis resultaterne af den første undersøgelse viser samme mønster som resultaterne af den anden, understøtter det både den foreslåede præpositionsklassifikation og etableringen af modifikationskriteriet som et fuldgyldigt alternativ til fokus- og adresserbarhedskriterierne.

I begge undersøgelser sammenlignes tale produceret af en agrammatisk taler i den kroniske fase, det vil sige mere end et år efter sygdomsdebut, med tale produceret af en normalttalende kontrolperson. Og i begge undersøgelser forventedes det, at den agrammatiske taler ville producere en signifikant lavere andel af grammatiske ord (hhv. præpositioner og verber) end kontrollen. Datamaterialet er baseret på eliciteret tale fra den agrammatiske taler og kontrolpersonen i tre forskellige genrer: beskrivende, fortællende og fri selvbiografisk tale. På dataindsamlingstidspunktet havde den agrammatiske taler levet med sine sprogvanskeligheder i mere end 25 år og havde modtaget forskellige former for genoptræning hen over årene. 
Efter en ortografisk transskription af datamaterialet blev alle præpositioner og verber opmærket og klassificeret som enten grammatiske eller leksikalske ved hjælp af modifikations- og fokuserbarhedskriterierne. Fx blev tili (24) (produceret af kontrolpersonen) og tili (25) (produceret af den agrammatiske taler) klassificeret som leksikalske, fordi de to forekomster kan modificeres af lige: hhv. lige frem til kanten og lige til søen.

... den er løbet lige så langt frem til kanten.

... frø pist væk for den er hop til søen...

Til sammenligning blev til i (26) (produceret af den agrammatiske taler), klassificeret som grammatisk, fordi det ikke kan modificeres. ... til bachelor læs om det læs det...

Klassifikationen var forholdsvis uproblematisk for kontrolpersonens vedkommende, men den agrammatiske taler substituerer eller udelader ofte ord, og derfor var klassifikationen ikke altid ligetil her. I tilfælde, hvor det var klart, at en præposition blev anvendt ukonventionelt som substitution for en anden præposition, blev klassifikationen baseret på en vurdering af, hvilken præposition der var blevet substitueret, og om denne var grammatisk eller leksikalsk. Fx vurderede vi, at præpositionen til i (27) var en substitution

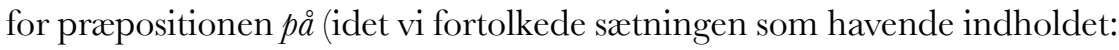
'glo på at parret måske kysser'), og vi klassificerede til som grammatisk, fordi hverken til eller på i denne sætning kan modificeres. ... glo til måske par kys...

Præpositioner, som efter vores vurdering blev anvendt som substitution for noget andet end en præposition, blev frasorteret. Det gælder fx til i (28), der rimeligvis anvendes som erstatning for en genitiv (drengens sko) i den agrammatiske talers beskrivelse af en sko på et billede. ... øh sko til dreng øh der svært...

Verber og præpositioner, der ikke med rimelighed kunne analyseres som substitutioner for elementer fra en anden ordklasse, og for hvilke klassifikationen som grammatisk eller leksikalsk ikke kunne afgøres med en vis rimelighed, klassificeredes som grammatiske. Dvs. de klassificeredes 
imod forventningen om, at grammatiske ord undgås i agrammatisk tale. Et eksempel på en sådan præposition er til i (29).

$$
\text { ... op fødder og øh til høj hals... }
$$

I undersøgelsen af verber havde den agrammatiske taler som forventet en signifikant lavere andel af grammatiske verber end kontrolpersonen. Resultaterne er illustreret i tabel 2.

\begin{tabular}{|l|l|l|l|l|}
\hline & \multicolumn{2}{|c|}{ Agrammatisk taler } & \multicolumn{2}{c|}{ Kontrolperson } \\
\hline & Antal & $\%$ af total & Antal & $\%$ af total \\
\hline Grammatiske verber & 17 & $8,13 \%$ & 91 & $36,70 \%$ \\
\hline Leksikalske verber & 192 & $91,87 \%$ & 157 & $63,30 \%$ \\
\hline
\end{tabular}

Tabel 2: Antal verber produceret af de to talere $i$ antal og procent af totalen. Signifikans er testet med Fishers eksakte test (en-halet), $p<0,001$.

Resultaterne af undersøgelsen af præpositioner viste, ligeledes som forventet, at den agrammatiske taler havde en signifikant lavere andel af grammatiske præpositioner i forhold til kontrolpersonen (tabel 3). Selv om forskellen mellem den agrammatiske taler og kontrolpersonen ikke er nær så slående for præpositionerne som for verberne, lader det alligevel til at mønstrene ligner hinanden.

\begin{tabular}{|l|l|l|l|l|}
\hline & \multicolumn{2}{|c|}{ Agrammatisk taler } & \multicolumn{2}{c|}{ Kontrolperson } \\
\hline & Antal & $\%$ af total & Antal & $\%$ af total \\
\hline Grammatiske præpositioner & 46 & $42,59 \%$ & 104 & $53,61 \%$ \\
\hline Leksikalske præpositioner & 62 & $57,41 \%$ & 90 & $46,39 \%$ \\
\hline
\end{tabular}

Tabel 3: Antal prepositioner produceret af de to talere $i$ antal og procent af totalen. Signifikans er testet med Fishers eksakte test (en-halet), $p<0,05$.

Klassifikationen af verber er ikke kontroversiel. Så når mønstret for præpositioner ligner mønsteret for verber, indikerer det, at klassifikationen virker. Datamaterialet understøtter altså en klassifikation af præpositioner i grammatiske og leksikalske baseret på modifikationskriteriet - og dermed parallellen mellem modifikationskriteriet på den ene side og fokus- og adresserbarhedskriteriet på den anden. 


\section{Konklusion}

Modificerbarhed kan anvendes som et nyt diagnostisk kriterium for leksikalsk status: Ifølge Boye \& Harder (2012) er grammatiske udtryk konventionelt sekundære, og det følger heraf, at de dårligt lader sig elaborere ved modifikation. Dette nye kriterium er særligt anvendeligt, når kategorier som præpositioner skal klassificeres som hhv. leksikalske eller grammatiske, fordi det ikke på samme måde som de andre diagnostiske kriterier er begrænset til sætningsled. På dansk kan leksikalske præpositioner fx modificeres af visse præpositionsmodificerende adverbier (bl.a. midt, kort, lige, umiddelbart). Ved hjælp af sådanne adverbier har vi klassificeret en række præpositioner i dansk mht. sondringen mellem grammatisk og leksikalsk. Vi har identificeret både præpositioner (eller præpositionsanvendelser eller -indhold), der kan klassificeres som leksikalske, og præpositioner (eller anvendelser eller indhold), der kan klassificeres som grammatiske. Den danske ordklasse præpositioner er med andre ord ikke homogen, hvad angår leksikalsk status.

Sondringen mellem leksikalske og grammatiske elementer afspejles i agrammatisk tale, som er en vigtig datakilde til afprøvning af teorier om leksikon og grammatik. Analysen af talesprogsdata fra en agrammatisk patient viste da også, at patienten netop har sværere ved at producere grammatiske præpositioner end leksikalske præpositioner. Denne nære sammenhæng mellem teori og data muliggør en mere præcis forståelse af begrebet grammatik, og en sådan mere præcis forståelse muliggør på sin side landvindinger inden for diagnosticering og behandling af patienter med agrammatisme.

\section{Om forfatterne}

Maria Messerschmidt, cand.mag. i lingvistik, Institut for Nordiske Studier og Sprogvidenskab, Københavns Universitet.

Kasper Boye, ph.d., Institut for Nordiske Studier og Sprogvidenskab, Københavns Universitet.

Mathilde Marie Overmark, stud.mag. i audiologopædi, Institut for Nordiske Studier og Sprogvidenskab, Københavns Universitet.

Sofie Theilmann Kristensen, stud.mag. i lingvistik, Institut for Nordiske Studier og Sprogvidenskab, Københavns Universitet.

Peter Harder, dr.phil., Institut for Engelsk, Germansk og Romansk, Københavns Universitet. 


\section{Litteratur}

Boye, K. \& Harder, P. (2012): A usage-based theory of grammatical status and grammaticalization. Language 88 (1), 1-44.

Bordet, L. \& Jamet, D. (2010): Are English prepositions lexical or grammatical morphemes? Cercles, Occasional Papers, 1-26.

Brink, E.T. (2014): Sproglig progression i kronisk afasi - et longitudinalstudium af en Broca-afatikers sproglige udvikling over 14 år. Specialeafhandling, Københavns Universitet.

Caplan, D. (2012): Ressource reduction accounts for syntactically based disorder. I: Perspectives on agrammatism. Bastiaanse, R. \& Thompson, G.K. (red.). London: Psychology Press, 34-48.

Chomsky, N. (1981): Lectures on Government and Binding. Dordrecht: Foris.

Dansk Sprognævn (2017): Retskrivningsordbogen online. https://dsn.dk/ro.

Friederici, A.D. (1982): Syntactic and semantic processes in aphasic deficits: The availability of prepositions. Brain and Language 15 (2), 249-258.

Harley, H. (2006): English words: A linguistic introduction. New York: John Wiley \& Sons.

Ishkhanyan, B., Sahraoui, H., Harder, P., Mogensen, J., \& Boye, K. (2017):

Grammatical and lexical pronoun dissociation in French speakers with agrammatic aphasia: A usage-based account and REF-based hypothesis. Fournal of Neurolinguistics 44, 1-16.

Jackendoff, R. (1973): The Base Rules for Prepositional Phrases. I: A Festschrift for Morris Halle. Anderson, S. \& Kiparsky, P. (red.). New York: Holt, Rienhart and Winston, 345-356.

Kean, M.-L. (1979): Agrammatism: A phonological deficit? Cognition 7, 69-83. Kristensen, L.B. \& Boye, K. (2016): Svært ved grammatikken, del 3. Logos 77, 27-31.

Kristensen, S.T. (2017): Verbumproduktionen hos en dansk agrammatiker. BAprojekt, Københavns Universitet.

Leikin, M. (2002): Locative prepositions in language acquisition and aphasia.

I: Prepositions in their syntactic, semantic, and pragmatic context. Feigenbaum, S. \& Kurzon, D. (red.). Amsterdam: Benjamins, 283--99.

Littlefield, H. (2005): Lexical and functional prepositions in acquisition: Evidence for a hybrid category. Boston University Conference on Language Development 29, Online Proceedings Supplement.

Mardale, A. (2011): Prepositions as a semilexical category. Bucharest Working Papers in Linguistics 13, 35-50.

O'Grady, W., Archibald J. \& Katamba, F. (2011): Contemporary linguistics: An introduction (2. udg.). Harlow: Longman - Pearson Education. 
Overmark, M.M. (2016): Et "til" fra eller til produktion af prepositioner $i$ kronisk agrammatisme. BA-projekt, Københavns Universitet.

Rauh, G. (1993): On the grammar of lexical and non-lexical prepositions in English. I: The semantics of prepositions. Zelinsky-Wibbelt, C. (red.). Berlin, Boston: de Gruyter Mouton, 99-150.

Thompson, C.K. \& Bastiaanse, R. (2012): Introduction to agrammatism. I: Perspectives on agrammatism. Bastiaanse, R. \& Thompson, C.K. London: Psychology Press, 5-30. 